Volume 5 Issue 2, July 2021

sisaddergi@gmail.com

Makale Türü/Article Type: Araştırma/Research

Makale Gönderim Tarihi/Received Date: 13.04.2021

Makale Kabul Tarihi/Accepted Date: 07.04.2021

DOI: $10.30692 /$ sisad.914978

\title{
THE METHODS AND TOOLS USED BY MANAGERS IN THEIR STRATEGIC DECISION MAKING PROCESSES
}

\author{
Yöneticilerin Stratejik Karar Verme Süreçlerinde Kullandı̆̆ı Yöntem ve Araçlar \\ Salih AYGÜN \\ İstanbul Milli Savunma Üniversitesi \\ ATASAREN Savunma Kaynakları Bölümü Yüksek Lisans Mezunu \\ ORCID ID: 0000-0003-4254-8202 \\ salih3298@gmail.com
}

\author{
Orhan SEZGIN \\ Dr. Öğr. Üyesi \\ Atlas Üniversitesi \\ Insan ve Toplum Bilimleri Fakültesi, İsletme (İngilizce) \\ ORCID ID: 0000-0002-2375-8805 \\ orhansezgin91@gmail.com
}

\begin{abstract}
Atıf/Citation: Salih Aygün, Orhan Sezgin (2021), "The Methods and Tools Used By Managers In Their Strategic Decision Making Processes”, Stratejik ve Sosyal Araştırmalar Dergisi, C.5, S.2 Temmuz 2021 s.281-293.
\end{abstract}

\begin{abstract}
Businesses operating in complex and highly changing business environment are faced with threats or opportunities while performing. The purpose of this research is revealing the difference between strategic management practices of businesses and the level of awareness of managers to these practices. Under this purpose, with strategic analysis, it was tried to determine level of implementation of strategic management practices and at what stage and how managers and employees play a role in these practices. In addition, it was investigated whether they made strategic planning, whether they found themselves strategic or to what extent they found strategic and, if any, the direction of their strategies. In this framework, the answers to the research questions "The effect of family control on institutionalization", "The relationship between Institutionalization and Strategic Planning Process" and "The Relationship between Institutionalization and Strategic Management Process" were investigated. For this study, a questionnaire was sent electronically to the managers and replies were analyzed. From research three results were obtained. Institutionalization increases as the control of family decreases; scope of strategic management and strategic planning increases, institutionalization also increases and family's control over the business decreases, institutionalization increases, and as the level of institutionalization increases, annual return increases.
\end{abstract}

Keywords: Strategic Management, Manager, Strategic Decision Making, Strategy, Business Management 
Öz: Günümüzün karmaşı ve rekabetçi iş ortamında faaliyet gösteren işletmeler, görevlerini yerine getirirken birçok tehdit veya firsat ile yüzleşmektedir. İşletmelerin sürdürülebilir bir operasyonel yaşama sahip olmak için yeni yönetim tarzlarına ihtiyaçları olabilir. Ekonomilerin temelini oluşturan işletmeler hem işlerini büyütmek hem de daha uzun bir operasyonel yaşam sürmeye yönelik bir yönetim tarzına ihtiyaç duymaktadırlar. Bu nedenle birçok işletme stratejik yönetime önem vermiş ve yönetimlerinde kullanmaya başlamıştır. Bu araştırmanın amacı, işletmelerin stratejik yönetim uygulamaları ile yöneticilerin bu uygulamalara yönelik farkındalık düzeyleri arasındaki ilişkiyi belirlemektir. Bu amaçla stratejik analiz ile stratejik yönetim uygulamalarının düzeyi ve bu uygulamalarda yönetici ve çalışanların hangi aşamada ve nasıl rol oynadıkları belirlenmeye çalışılmıştır. İşletmelerin stratejik planlama yapıp yapmadıkları, kendilerini stratejik bulup bulmadıkları veya ölçüsü ve varsa stratejilerinin yönü araştırılmıştır. Bu çerçevede "Aile kontrolünün kurumsallaşma üzerindeki etkisi", "Kurumsallaşma ve Stratejik Planlama Süreci arasında ilişki" ve "Kurumsallaşma ve Stratejik Yönetim Süreci arasında ilişki” araştırma sorularının cevapları araştırılmıştır. Çalışma için anket soruları kendisine ulaşılabilen 49 yöneticiye elektronik ortamda gönderilmiş ve 30 kişiden cevap alınmıştır. Araştırmadan 3 sonuç elde edilmiştir. İlk olarak şirket üzerindeki aile kontrolü azaldıkça kurumsallaşma artmaktadır, ikinci olarak stratejik yönetim ve stratejik planlamanın kapsamı arttıkça, kurumsallaşma arttığı tespit edilmiştir ve son olarak kurumsallaşma düzeyi arttıkça yıllık cironun arttı̆g 1 belirlenmiştir.

Anahtar Kelimeler: Stratejik Yönetim, Yönetici, Stratejik Karar Verme, Strateji, İ̧̧ Yönetimi

\section{INTRODUCTION}

Although the concept of management is very old, the concept of business management is a concept that emerged about a century ago and is still under development. The reason why the concept of business management is so new is that there were no large-scale enterprises based on production until the industrial revolution that started in the 18th century. From this point of view, it is possible to characterize the time before the industrial revolution as the concept of business management as "pre-era" or "pre-scientific era" (Mouhoumed, 2015, pp. 10-12). However, considering that there were people and communities that came together, ruled, and managed in the past to achieve the same goal, it is possible to say that management activity existed even in ancient times.

Management is all of the planning, organizing, executing, coordination and control activities that are management functions in order to achieve organizational goals effectively and efficiently. Management is a universal process. It is an ancient art and a developing science, like social life. Management as a process means a set of activities and functions, management as an art means a practice, and management as a science means systematic and scientific knowledge community (Paşaoğlu et al., 2013, p. 3). The need for management arises from the need to achieve goals that people cannot achieve alone, through a group effort.

Strategic management, on the other hand, is a concept obtained by combining the concepts of strategy and management. Therefore, it is necessary to give information about the concept of strategy. Strategy can be defined as a collection of dynamic decisions based on a long-term perspective, focused on the final result, determining how the business will achieve its goals, including monitoring the activities of competitors (Tokgöz et al., 2014, pp. 3-4). Strategic management can be defined as the science and art of making, implementing, and evaluating interfunctional decisions that will enable the organization to achieve its goals (Çelik, 1994, pp. 2834). Today, various definitions have been made for the concept of strategic management; however, it is very difficult to make a clear definition. However, to summarize, for the definition of the concept of strategic management; In an increasingly competitive environment, the senior managers of organizations analyze the internal and external environment in order to achieve its goals in the long term, develop a set of cross-functional plans in this direction, evaluate, select, implement, and then audit the implemented plans. Taking all kinds of measures within the organization for the implementation of these plans falls under the field of activity of senior managers (Çetinkaya \& Gülbahar, 2019, p. 350). This whole process can be defined as strategic management. 
Strategic management refers to the development, planning, implementation and control of effective strategies for an organization to achieve its goals. In other words, strategic management is an area of research that examines what companies, facing an overwhelming competition, should do and follow what strategies to compete with their competitors (Bayraktar et al., 2020, p. 62). Strategic management is about the creation, implementation, monitoring and control of organizational strategies.

Every business carries out many activities designed to create products or services that it has undertaken to sell, deliver or distribute to individual or corporate customers. Customers should also be willing to accept, request, obtain and pay for these products or services. This current situation may change over time. Because customers may turn to other businesses in the face of more affordable or quality products / services of competitors or as a result of changes in their own wishes and reference frames. Businesses constantly resort to strategic management in order to adapt to the change of such current conditions. This adaptation may require a change in any part or direction of the organization's operations. Products or services may change, the methods of producing them may change, and the customers to whom the products or services are offered may change. Businesses usually have to make new arrangements for three reasons (Moseley III, 2009, pp. 15-18). These reasons;

- To reward or satisfy its stakeholders,

- Achieving or maintaining its mission,

- Maintaining operational life.

\section{Basic Concepts of Strategic Management and Development of Strategic Management Thinking}

The term strategic management has entered the business management literature since the 1980s and has been an approach that is still used extensively. This term is derived from the combination of strategy and management words. To give a definition, strategic management is the long-term management of all functions and elements of the business in a holistic approach to create the future beyond the relations with the environment of the business (Aktan, 2008, p. 5). Strategic management is a management focused on carrying an organization to its goals. The word goal is very important here. A company that does not have a very specific goal is a company that does not know where it is going, has left itself to international and national winds, and has attributed success to chance (Ertuna, 2008, p. 11). Sun Tzu drew attention to the importance of the issue, saying "War is won at headquarters". Although the concept of strategy in the military field started to be used in the business world in the 1940s in American companies, it was passed into the literature as a management concept by Robert Mc Namara, the president of Ford Motor Company, in 1953 (Karakaya \& Çoban, 2010, p. 343).

Decisions on strategic issues become concrete within the framework of a strategic plan and guide implementation. The strategic plan is a practical guide for implementation, based on the examination of internal and external environmental factors, guiding the goal setting and resource allocation in order to achieve meaningful results in the long term. It is stated that large-scale plans for the future, which are interactive with the competitive environment, are effective in achieving organizational goals (Pearce \& Robinson, 1996, p. 908). It has been argued that strategic planning systematizes the processes that will ensure the realization of the goals and objectives of the organization (Crittenden \& Crittenden, 2000, pp. 150-152).

Strategic planning consists of the processes of developing a plan, defining the organization, explaining organizational goals and values, evaluating external and internal environmental factors, defining strategic issues, reviewing and adapting the strategy and plan, developing the vision of the organization, implementation and finally re-evaluating the strategy and planning process (Price et al., 2003, pp. 347-349). 
Strategic planning is constantly updated. Strategic planning is systematic; it is not accidental or instinctive but has a certain method and course. Strategic planning is process; rather than a result, it is a journey where strategists work together and take responsibility. The strategy is made by certain people, they need to be involved in decisions and be willing. The strategic management process, which also includes strategic planning, is defined as all information gathering, analysis, selection, decision and implementation activities aimed at sustaining the business in the long term and providing a sustainable competitive advantage (Ülgen \& Mirze, 2013, pp. 15-17).

Strategic management thinking goes back to ancient times as an approach. Military wars in particular are full of examples of strategic management approaches. However, these examples are products of the "Unscientific Management" era.

In order for strategic management thought to become scientific, management thought had to begin to become scientific first. This formation coincides with the post-industrial revolution, approximately in the 1880s. With the scientification of management thought, the theoretical framework of management practices was formed, and management functions were defined (Söyler, 2007, pp. 103-105). The development of strategic management thinking is outlined in Table-1.

Table 1: Development of Strategic Management Thought

\begin{tabular}{|l|l|l|}
\hline Period & \multicolumn{1}{|c|}{ Phases } & \multicolumn{1}{c|}{ Features } \\
\hline 1880 & Scientific Management Period & \multicolumn{1}{c|}{} \\
\hline 1950 & Planning & $\begin{array}{l}\text { Visible future, piecemeal approach, point to be reached, closed } \\
\text { organization }\end{array}$ \\
\hline 1960 & Long Term Planning & Long future, time horizon \\
\hline 1965 & Collective Planning & System view, holistic approach, internal interaction \\
\hline 1970 & Strategic Planning & Setting direction, drawing route \\
\hline 1980 & Strategic Management & Open organization, interaction with the environment, feedback \\
\hline 1985 & Strategic Scenarios & Alternative directions, alternative routes, scenarios \\
\hline 1990 & Strategic Opinion & Unforeseen future, unknown environment, strategic values, culture \\
\hline
\end{tabular}

Reference: (Akgemci, 2007, p. 11)

In this context, Ülgen and Mirze (2013) divided the strategic management into seven phases.

1. Strategic awareness: The strategic management process starts with the strategic awareness of business managers.

2. Selecting and evaluating strategists: This phase is so important due to the strategists, who are involved in the implementation of the strategies determined at every level of the company, from inside or outside the company, are of key importance in the selection and implementation of strategies.

3. Strategic analysis: The strategic analysis process is the evaluation of the internal situation of the enterprise and the examination of the general and sectoral environment in which the enterprise exists.

4. Strategic guidance: In this phase, the vision, mission, and objectives of the enterprise are determined, and a job description is made.

5. Strategy formulation: In this phase, analysis has been made and objectives have been determined. Strategists work to choose the most suitable strategy for the company.

6. Strategic implementation: At this stage, the strategy or strategies are now chosen, and studies have started to put them into practice. Managers have mobilized business resources for these strategies. The issue that needs to be considered at this stage is that all units of the company adopt this strategy and are willing to achieve it.

7. Strategic control: In this phase, the conditions of the strategic management process are constantly changing and developing, as the strategic management process is dynamic. Sometimes reactive and sometimes proactive strategies may be required to keep up with 
these changing conditions. This phase should be implemented not only while implementing the strategy, but also at all stages in order to control this process (Ülgen \& Mirze, 2013, pp. 550-552).

In today's management approach, it does not seem possible to manage an organization without strategic thinking. The manager needs to know the strategic position of the organization, understand the impact of changing conditions, monitor the company's internal and external environment, and choose the right time to change strategy. Strategic management is the most exciting aspect of the management discipline. Strategic management is about success and failure, about the ability to plan battles and defeat opponents. An effective strategic management performance can transform an organization, ideally allocate wealth to shareholders or change the structure of an industry (Kirkpatrick, 2016, p. 106).

Strategic management is not limited to a set of routine rules, procedures, and programs. It has a theory that explains what to do to solve problems or situations. Strategic management is the philosophy or ideology of business and management. Every manager understands this ideology and largely integrates it in its own way (Kayar Çelik \& Aytar, 2019, p. 132). The fact that managers have a strategic management approach also contributes to the institutionalization level of the organization. Manager, organizational structure, and strategy fit positively affect organizational commitment and success.

\section{Strategic Management Methods and Tools}

Strategic management is a management technique that reveals what an organization does, the reason for its existence and the goals it wants to achieve in the future. Strategic management is a special management style that does not eliminate basic management functions such as planning, organizing, executing, and controlling, that the upper level is interested in. Strategic management is the process of planning, organizing, coordinating and controlling the work to be done in order to bring the organization to the desired location (Brayson, 1995, pp. 5-6).

Strategic management can be called a roadmap for the future. As you walk through this roadmap, there are variable actors to use. Aiming to manage the future and bringing a dynamic structure to the organization can only be achieved by benefiting from these actors enough. Only in this case will it be possible to achieve excellence in strategic management (Baykal, 2018, p. 152).

Businesses need some strategic management methods and tools that will assist them while implementing their activities in the difficult environmental conditions they are in and provide a competitive advantage over their competitors (Akgemci \& Celik, 2010, pp. 50-52). The most common of these tools in the literature are SWOT Analysis, Balanced Scorecard, Cost Benefit Analysis, Supply Chain Management, Risk Analysis, Critical Success Factors analysis, Outsourcing and Scenario Development.

1. Swot Analysis: Businesses are faced with many threats and opportunities due to the economic conditions they are in. For this reason, it is for businesses to analyze the market they are in with a more systematic perspective and to analyze the opportunities and threats arising from environmental conditions, and then to determine their own strengths and weaknesses (Akgemci \& Çelik, 2010, pp. 70). The main purpose is to determine the strengths and weaknesses that will provide competitive advantage against competitors. This process then emerges as a method that guides firm strategies to evaluate opportunities and counter threats based on strengths and weaknesses.

2. Balanced Scorecard: The transition from the industrial society to the information society has led to significant changes in the business world, as in all areas of life. Business environments arranged according to the conditions in the industrial society can no longer meet the needs. The Balanced Scorecard method contributes to the achievement of the goals of the enterprises by bringing effective solutions to the problem of failure in strategic applications and the inadequacy of traditional performance systems faced 
by information society enterprises. The balanced scorecard aims to find solutions to the problems faced by the enterprises in the field of performance evaluation by presenting a framework in which the vision, mission and strategy of the enterprise are transformed into performance criteria including non-financial criteria (Güner, 2008, pp. 247-249).

3. Benefit-Cost Analysis: Benefit-Cost analysis is the method used to help strategists make comparisons between alternative approaches and options. The main purpose of costbenefit analysis is to generate information for decision-makers about estimating the monetary equivalent of the benefits and costs of a particular activity or project and comparing it with different decisions. This method of analysis is generally used for situations that can be measured with money (Hastürk, 2006, pp. 81-83).

4. Supply Chain Management: In today's challenging competitive conditions, many companies have understood the strategic importance of supply chain management in order to gain competitive advantage and for this purpose, companies have started to build their relations with their suppliers and customers on mutual benefit and cooperation (Güleş, 1999, p. 3).

5. Risk Analysis: It is the analysis made to determine how risky the investment to be made is. Risk analysis consists of "economic-financial risk", "political risk", "country risk" and other analyzes. In recent years, risk analysis has been widely used, especially in foreign capital investments. The number of rating agencies that conduct credit evaluation and risk analysis for countries in need of foreign debt has increased rapidly in recent years (Aktan, 2005, pp. 25-27).

6. Critical Success Factors Analysis: Critical success factors analysis can be defined as the factors that make it easier for the businesses in almost all business lines to have success. In other words, we can say that these factors are the "tricks of the job" that should be considered in order to achieve success. These factors may be related to the company's own capability or to external environmental factors (Mirze, 2014, p. 142).

7. Outsourcing: Outsourcing is the execution of the works that are outside of the main field of activity of the enterprise through external expert enterprises. In other words, the company leaves some or all of the work to a specialist service provider or supplier with an agreement made for activities other than its core competencies (Özgener, 2004, p. 172).

8. Scenario Development: Businesses can operate in a rapidly changing and sometimes uncertain future environment. In this case, it is not sufficient to determine the current situation alone and to determine the appropriate strategies for these determinations. Because very different, unimaginable, and surprising events can occur in volatile and fragile environments. In such undesirable situations, businesses should determine their course of action (Mirze, 2014, p. 147).

9. Risks: Decision makers may face three risks of being in the strategy formulation process. First, decision makers may not have enough time to fulfill their operational responsibilities by focusing on the strategy formulation process. Managers must have the necessary competence to organize it. The second occurs when the strategy creator and the implementers of this strategy are different managers. In this case, strategic managers may not accept their responsibilities in the decisions taken. Third, a participant involved in any stage of strategy formulation can put himself under expectation. Strategic managers should analyze this situation correctly and guide the participants correctly (Pearce \& Robinson, 1996, p. 908).

Strategic management has gained a new dimension with the changing and developmental values that have emerged over time. The new ideas that arise are necessary for the development and success of the organization. These ideas brought along some regulations and structured elements 
such as strategic conditions at different stages with different tools. Strategic management, which is a cycle of strategic change, gives direction to basic policies, such as external demands and possibilities, brainstorming, problem-solving techniques, vision, and mission statements, in order for the organization to survive and provide a developed and effective organization (Baykal, 2018, p. 132).

\section{Materials and Methods}

In the first part of the study, a preliminary introduction was made for the main idea of the article, in the second part, the basic concepts of strategic management and the development of strategic management thought were discussed, and in the third part, the strategic management methods and tools used by the managers were discussed. In the last section, the purpose, scope, method, analysis of the research, findings and their interpretations will be emphasized.

The purpose of this research is to reveal the difference between the strategic management practices of the businesses operating in İstanbul and the level of awareness of the managers to these practices. Under this purpose, with strategic analysis, it has been tried to determine the level of implementation of strategic management practices and at what stage and how the managers and employees play a role in these practices. In addition, it was investigated whether they made strategic planning, whether they found themselves strategic or to what extent they found strategic and, if any, the direction of their strategies.

In this framework, the answers to the research questions "The effect of family control on institutionalization", "The relationship between Institutionalization and Strategic Planning Process" and "The Relationship between Institutionalization and Strategic Management Process" were investigated. In the universe of the research, there are managers at various levels of the businesses in Istanbul. It is aimed to examine the methods used by managers in the strategic decision-making process. For this study, questionnaire questions were sent electronically to 49 managers and 30 replies were received.

The questionnaire used as data collection tool consists of 3 parts. In the first part, there are 14 questions about the demographic characteristics of the employees and general and descriptive information about the company. In the second part of the questionnaire, the Strategic Management Process questionnaire was used (Eren et al., 2000, p. 333). The Strategic Planning Process scale was used in the third and last part of the questionnaire (K1lc1, 2013, pp. 85-90).

\section{Analysis and Findings}

$70 \%$ (21) of the participants who answered the questionnaire in the research are men and $30 \%$ (9) of them are women. 16.7\% (5) of these participants are lower-level managers, $60 \%$ (18) middlelevel managers and $23.3 \%$ (7) senior manager. When the educational status of the participants is examined, $20 \%$ (6) of them have postgraduate education, while the remaining $80 \%$ (24) have graduate education. $26.7 \%$ (8) of the participants work in joint stock companies, $10 \%$ (3) in limited liability companies and $63.3 \%$ (19) in limited companies. When the annual return of the companies is examined, it is seen that $63.3 \%$ (19) have a return of 5 million TL and below, while the remaining $36.7 \%$ (11) have a return above 5 million TL. When the management structure of the companies is examined, it is seen that the control of the family is very low in $66.7 \%$ (20), while the family control is low and medium in the remaining $33.3 \%$ (10). Data on participants and companies are presented in detail in Table- 2 . 
Table 2: Information on Participants

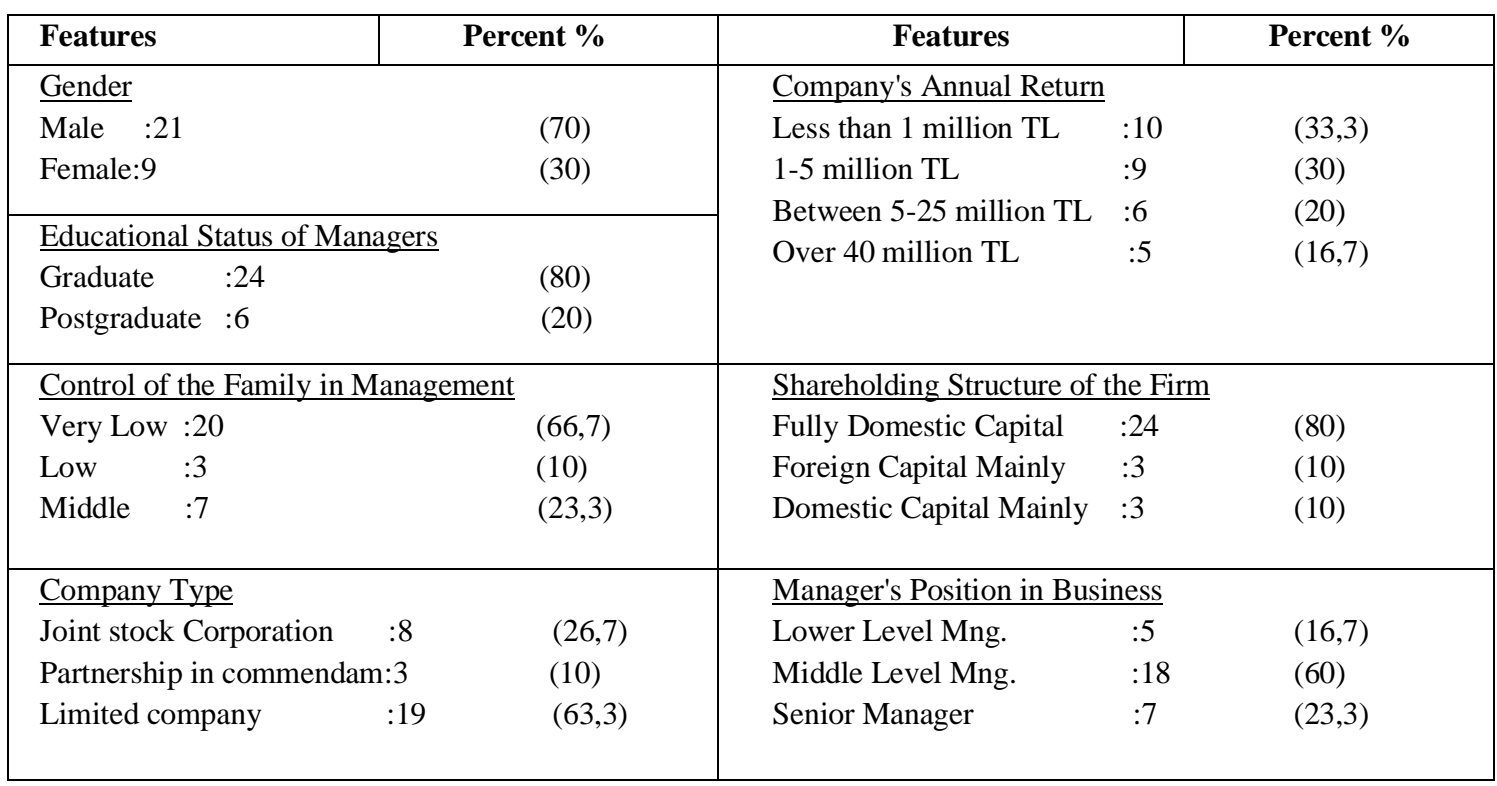

10 of the companies do the strategic planning for 1 year or less, 9 for a period of 3 to 5 years, and the remaining 11 for more than 5 years. What is interesting here is that 10 companies consider plans less than a year as strategic plans. Considering this information, we can say that 20 companies $(66.7 \%)$ have a strategic plan for more than 1 year. The data regarding the strategic plan duration are presented in Table-3.

Table 3: Strategic Plan Duration

\begin{tabular}{|l|c|c|}
\hline & Frequency & Rate \\
\hline 1 year and less & 10 & 33,3 \\
\hline 3 to 5 years & 9 & 30,0 \\
\hline More than 5 years & 11 & 36,7 \\
\hline
\end{tabular}

Table 4: Contributors to the Strategic Plan Process

\begin{tabular}{|l|c|c|}
\hline & Frequency & Rate \\
\hline Functional Units & 11 & 36,7 \\
\hline Business Owners & 7 & 23,3 \\
\hline Senior Managers & 9 & 30,0 \\
\hline Board of Directors & 3 & 10,0 \\
\hline
\end{tabular}

In Table-4, there are the units that contribute to the creation of the strategic plan and the frequency distributions containing the answers given to the questions. When we examine this table, it is seen that functional units contribute $36.7 \%$, business owners $23.3 \%$, senior managers $30 \%$ and the board of directors $10 \%$, contributing to the creation of a strategic plan. As can be understood from this information, managers with executive power contribute to the creation of the strategic plan.

Table 5: Strategic Management Process

\begin{tabular}{|l|c|c|l|}
\hline Strategic Management Process & Mean & $\begin{array}{c}\text { Standard } \\
\text { Deviation }\end{array}$ & \multicolumn{1}{|c|}{ Remark } \\
\hline There are certain basic aims and objectives of the company & 4,90 &, 498 & Totally agree \\
\hline Our company has a specific mission & 4,60 &, 498 & Totally agree \\
\hline $\begin{array}{l}\text { After a strategy is determined, plans and budgets are made } \\
\text { accordingly. }\end{array}$ & 4,60 &, 305 & Totally agree \\
\hline Our company has a specific vision & 4,63 &, 490 & Totally agree \\
\hline
\end{tabular}




\begin{tabular}{|l|c|c|l|}
\hline $\begin{array}{l}\text { When determining the strategy, opportunities and threats in the } \\
\text { environment are examined }\end{array}$ & 4,53 &, 507 & Totally agree \\
\hline $\begin{array}{l}\text { Information about customer needs and preferences in the } \\
\text { market is collected during the strategy planning phase }\end{array}$ & 4,43 &, 504 & Agree \\
\hline $\begin{array}{l}\text { Information about competitors in the market is collected during } \\
\text { the strategy planning phase }\end{array}$ & 4,53 &, 507 & Agree \\
\hline $\begin{array}{l}\text { Strengths and weaknesses of our company are determined } \\
\text { while determining the strategy }\end{array}$ & 4,23 &, 898 & Agree \\
\hline $\begin{array}{l}\text { Information on general economic development and } \\
\text { expectations is collected during the strategy planning phase }\end{array}$ & 4,13 & 1,167 & Agree \\
\hline $\begin{array}{l}\text { After the determined strategy is implemented, the effectiveness } \\
\text { of the results is evaluated }\end{array}$ & 4,10 & 1,155 & Agree \\
\hline $\begin{array}{l}\text { During the strategy planning phase, information about our } \\
\text { suppliers in the market is collected }\end{array}$ & 3,73 & 1,230 & Agree \\
\hline $\begin{array}{l}\text { Various alternative strategies are determined before a strategy } \\
\text { is determined }\end{array}$ & 4,73 &, 450 & Agree \\
\hline $\begin{array}{l}\text { During the strategy planning phase, information about the } \\
\text { distributors (e.g., retailers) in the market is collected }\end{array}$ & 4,40 &, 498 & Agree \\
\hline $\begin{array}{l}\text { During the strategy planning phase, information about general } \\
\text { technological developments and expectations is collected }\end{array}$ & 4,23 &, 490 & Agree \\
\hline $\begin{array}{l}\text { Information on general demographic development and } \\
\text { expectations is collected during the strategy planning phase }\end{array}$ & 4,10 &, 845 & Agree \\
\hline As it is understogd from Table-5, the activity that compang
\end{tabular}

As it is understood from Table-5, the activity that companies attach the most importance to in the strategic management process is to establish the main goals and objectives $(4,90)$. This is followed by developing a vision (4.63) and planning and budgeting in accordance with the strategy (4.60) and developing a mission (4.60). Relatively less important issues are followed by supplier information (3.73) and demographic developments (4.10). As can be understood from here, mission, purpose, and budget; it is not built on medium- and long-term macro trends in suppliers and demographic areas.

Table 6: Strategic Planning Process

\begin{tabular}{|l|c|c|l|}
\hline Strategic Planning Process & Mean & $\begin{array}{l}\text { Standard } \\
\text { Deviation }\end{array}$ & Remark \\
\hline $\begin{array}{l}\text { Senior managers take responsibility for the firm's strategic } \\
\text { planning }\end{array}$ & 4,50 &, 509 & Agree \\
\hline The firm takes strategic decisions based on the strategic plan & 4,20 &, 407 & Agree \\
\hline $\begin{array}{l}\text { Firm provides resources (time, money, personnel support) for } \\
\text { strategic planning }\end{array}$ & 4,13 &, 860 & Agree \\
\hline $\begin{array}{l}\text { Strategic planning is the top priority activity and is carried out } \\
\text { regularly every year }\end{array}$ & 4,00 & 1,114 & Agree \\
\hline $\begin{array}{l}\text { For a successful performance, individuals bear the } \\
\text { responsibility of strategic planning and implementation }\end{array}$ & 4,53 &, 507 & Agree \\
\hline $\begin{array}{l}\text { The firm initially assumes responsibility for the } \\
\text { implementation of an action plan on a person or alternatively } \\
\text { on a team }\end{array}$ & 4,00 & 1,114 & Agree \\
\hline $\begin{array}{l}\text { All managers, who will be significantly affected by strategic } \\
\text { planning, participate in the planning process }\end{array}$ & 4,63 &, 490 & Agree \\
\hline $\begin{array}{l}\text { The firm regularly reviews monitoring data and revises } \\
\text { strategic decisions as appropriate }\end{array}$ & 4,00 &, 788 & Agree \\
\hline $\begin{array}{l}\text { The firm follows a predetermined set of procedures in the } \\
\text { strategic planning process }\end{array}$ & 4,23 &, 898 & Agree \\
\hline $\begin{array}{l}\text { The firm sets clearly defined and measurable performance } \\
\text { standards for each plan item }\end{array}$ & 4,00 &, 788 & Agree \\
\hline $\begin{array}{l}\text { The firm uses strategic (situational) diagnostics to formulate } \\
\text { strategic plan options }\end{array}$ & 3,93 & 1,081 & Indecisive \\
\hline $\begin{array}{l}\text { The firm develops an organized system to monitor how well } \\
\text { these performance standards are met }\end{array}$ & 3,80 & 1,270 & Indecisive \\
\hline
\end{tabular}


As can be seen from Table 5, the most important activities of the companies in the strategic planning process are the participation of all managers in the strategic planning activity $(4,63)$, individuals bearing the responsibility of strategic planning and implementation for a successful performance $(4,53)$, and senior managers to take responsibility in the strategic planning of the firm (4.50). Relatively less important issues are making strategic (situational) diagnostics to formulate strategic plan options (3.93) and developing systems to monitor to what extent performance standards have been achieved (3.80). As it can be understood from here, although the top managers of the companies take responsibility for the strategic planning process and provide resource support such as time, money and personnel and give their strategic decisions to the strategic plan, they should give more importance to the issues of making current situation analysis and improving the performance evaluation system.

Table 7: Correlation Analysis

\begin{tabular}{|l|c|c|c|c|}
\hline & $\begin{array}{c}\text { Institutionalization } \\
\text { Level of the } \\
\text { Company? }\end{array}$ & $\begin{array}{c}\text { Family Control in } \\
\text { Management? }\end{array}$ & $\begin{array}{c}\text { Strategic } \\
\text { Management } \\
\text { Process }\end{array}$ & $\begin{array}{c}\text { Strategic } \\
\text { Planning } \\
\text { Process }\end{array}$ \\
\hline $\begin{array}{l}\text { Institutionalization Level of the } \\
\text { Company? }\end{array}$ & 1 &,$- 512^{* *}$ &, 331 &, $436^{*}$ \\
\hline Family Control in Management? &,$- 512^{* *}$ & 1 &, 196 &,- 118 \\
\hline Strategic Management Process &, 331 &, 196 & 1 &, $627^{* *}$ \\
\hline Strategic Planning Process &, $436^{*}$ &,- 118 &, $627^{* *}$ & 1 \\
\hline
\end{tabular}

**. Correlation is significant at the 0.01 level (2-tailed).

*. Correlation is significant at the 0.05 level (2-tailed).

According to the correlation analysis findings, significant relationships were found between many factors. Namely;

1. It is seen that there is a negative relationship (-,512) between the level of institutionalization and family control. According to this relationship, as the family control decreases, the level of institutionalization increases.

2. There is a positive relationship between the level of institutionalization and the strategic planning process (,436). Accordingly, as the strategic planning process increases, the institutionalization level of the firm increases.

3. Likewise, there is a positive relationship between the strategic management process, the institutionalization level $(, 331)$ and the strategic planning process (,627). Accordingly, as the scope of the company's strategic management and strategic planning process increases, the level of institutionalization also increases.

Studies on similar subjects in the literature, conducted using different methods and tools, have been examined. Among these studies, there are studies that find results parallel to the results of the study.

In Alcan, Esmer and Alcan (2021) study, it was tried to develop a strategy for the use of photovoltaic systems in accommodation businesses by integrating SWOT analysis and AHP method. Using the data obtained as a result of the SWOT analysis, 4 strategies were developed, and then the most suitable strategy was tried to be determined by AHP method (Alcan et al., 2021, p. 360).

In Esmer (2019) study, it is aimed to make financial strategic analysis of businesses. In line with this purpose, data were collected from 10 busines managers operating in Amasya via the "Financial Strategic Analysis Form". The collected data are analyzed with the SWOT analysis technique, and the financial advantages and weaknesses of the enterprises, as well as financial threats and opportunities are determined. In addition, as a result of the SWOT analysis, 4 financial strategies have been developed for businesses (Esmer, 2019 p. 82). 


\section{CONCLUSION AND RECOMMENDATIONS}

Strategic management is a process which focuses on the long-term goals and objectives of the organizations and tries to provide sustainability. Especially in highly changing business environment importance of strategic management increases. In order to challenge with uncertainty, organizations should implement the necessary steps and processes of strategic management.

The purpose of this study is to reveal the level of implementation of strategic management and awareness of strategic management of various business organizations operating in Istanbul. Therefore, in the last part of the study, suggestions on the subject are presented by evaluating the findings obtained from the research.

Business organizations are of great importance for the country's economy. Operating in today's complex and highly competitive business environment, these businesses are faced with many threats or opportunities while performing their duties. Sometimes they can resist these threats with the advantages they have, and sometimes they can be defeated. For these reasons, companies need strategic management.

When the literature is examined, many processes are prevented from being managed by a professional manager in businesses with high family control. The important finding about this issue in the study is that institutionalization increases as the control of the family decreases in the organizations. Another finding obtained from the study is that as the scope of strategic management and strategic planning increases, institutionalization also increases. As it seems, strategic management can be effective on many variables. According to the results of the study, it has been determined that as the family's control over the business decreases, institutionalization increases, and as the level of institutionalization increases, the annual return increases. It has been observed that as the scope of the strategic management process and strategic planning process increases, institutionalization increases. Strategic decision makers in business organizations may need to pay attention to this information when they prepare their strategic plans.

Studies on similar subjects in the literature, conducted using different methods and tools, have been examined. Among these studies, there are studies that find results parallel to the results of the study '(Alcan et al., 2021, p. 360); (Esmer, 2019 p. 82)'.

As a result, it can be said that in today's highly changing business environment importance of strategic management is increasing and companies have to challenge with different types of difficulties. Strategic management process and strategic planning need a professional focus and vision. As seen from the study when the control of the family on business decreases the level of institutionalization and the level of strategic management increases. So, for better results and long-term sustainability, business organizations need more institutionalization and need to give more opportunities to the professional managers for decision making and control over their responsibilities. 


\section{REFERENCES}

Akgemci, T. (2007). Stratejik Yönetim. Ankara: Gazi Kitapevi.

Akgemci, T., Çelik, A. (2010). Girişimcilik Kültürü ve KOBİ'ler. Ankara: Gazi Kitapevi.

Aktan, C. C. (2005). Geleceği Kazanmanın Yolu Stratejik Yönetim. Çimento İşveren Dergisi, 1, $1-58$.

Aktan, C. C. (2008). Stratejik Yönetim ve Stratejik Planlama. Çimento İşveren Dergisi, (22)4, 415.

Alcan, Ö., Esmer, Y., \& Alcan, Y. (2021). Strategy Development for the Applicability of Photocoltaic Systems in Hospitality Enterprises Using SWOT Analysis and AHP Method: The CAse of Sinop Province. Duzce Universitesi Bilim ve Teknoloji Dergisi, 9, 360-375.

Baykal, T. (2018). Örgütlerde Etkinlik ve Etkililik için Stratejik Yönetim ve Stratejik Planlama. Sosyal Bilimler Araştırma Dergisi, 7(2), 151-160.

Bayraktar, E., Turan, E., \& Çetin, S. (2020). Stratejik Yönetim Kültürü ve Belediyeler: TR82 Bölgesi Belediyeleri Üzerine Bir İnceleme. Kastamonu Üniversitesi İktisadi ve İdari Bilimler Fakültesi Dergisi, 22(1), 55-89.

Brayson, J. M. (1995). Strategic Planning for Public and Nonprofit Organizations (A Guide to Strengthening and Sustaining Organizational Achievement). San Francisco: Jossey.

Çelik, V. (1994). Etkili Bir Okul İçin Stratejik Yönetim. Eğitim ve Bilim Dergisi, 13(1), 28-34.

Çetinkaya, F. F., \& Gülbahar, H. O. (2019). Stratejik Yönetim ve İnovasyon İlişkisi: KOBİ'ler Üzerine Bir Araştırma. Ahi Evran Üniversitesi Sosyal Bilimler Enstitüsü Dergisi, 5(2), 349367.

Crittenden, W. F., \& Crittenden, V. L. (2000). Relationships Between Organizational Characteristics and Strategic Planning Processes in Nonprofit Organizations. Journal of Managerial Issues, 12(2), 150-168.

Eren, E., Aren, S., \& Alpkan, L. (2000). İşletmelerde Stratejik Yönetim Faaliyetlerini Değerlendirme Araştırması. Doğuş Üniversitesi Dergisi, 1, 96-122.

Ertuna, Ö. (2008). Stratejik Yönetim. İstanbul: Okan Üniversitesi Yayınları.

Esmer, Y. (2019). Financial Strategic Analysis In SMEs: The Case of Amasya Province. Research of Financial Economic and Social Studies (RFES, 1(1), 82-88.

Güleş, H. K. (1999). Elektronik Veri Değişiminin Tedarik Zinciri Yönetimindeki Yeri. Selçuk Üniversitesi Sosyal Bilimler Meslek Yüksekokulu Dergisi, 3, 1-16.

Güner, M. F. (2008). Bir Stratejik Yönetim Modeli Olarak Balanced Scorecard. Gazi Üniversitesi İktisadi ve İdari Bilimler Fakültesi Dergisi, 1(10), 247-265.

Hastürk, M. (2006). Stratejik Planlama ve Performans Esaslı Bütçeleme Raporu. Maliye Bakanlığı Bütçe ve Mali Kontrol Genel Müdürlüğü. Ankara: Maliye Bakanlığı.

Karakaya, Y. E., \& Çoban, B. (2010). Geleceği Planlamada Stratejik Yönetim ve SWOT Analizi Kavramsal Yaklaşımlar. E-Journal of New World Sciences Academy, 5(4), 342-352.

Kayar Çelik, B., \& Aytar, O. (2019). Örgütlerde Stratejik Yönetim Farkindalığı: Kırşehir İli Örneği. Avrasya Sosyal ve Ekonomi Araştırmaları Dergisi, 6(8), 129-146.

Kirkpatrick, S. A. (2016). Build a Better Vision Statement. New York: Lexington Books.

Kılcı, H. (2013). Küçük ve Orta Ölçekli İşletmelerde Stratejik Yönetim Uygulamaları Tokat İli İmalat KOBI'leri Üzerinde Bir Çalışma. Yayımlanmamış Yüksek Lisans Tezi, 
Gaziosmanpaşa Üniversitesi Sosyal Bilimler Enstitüsü, Tokat, Türkiye.

Mirze, K. (2014). İşletmelerde Stratejik Planlama. Ankara: Nobel Yayıncılık.

Moseley III, G. B. (2009). Managing Health Care Business Strategy. London: Jones and Bartlett Publishers.

Mouhoumed, İ. M. (2015). İşletme Yöneticilerinin Stratejik Yönetim Uygulamalarını Belirlemeye Yönelik Bir Araştırma. Yayımlanmamış Yüksek Lisans Tezi, İnönü Üniversitesi Sosyal Bilimler Enstitüsü, Malatya, Türkiye.

Özgener, Ş. (2004). Çağdaş Yönetim Yaklaşımları, Bir Yönetim Stratejisi Olarak Outsourcing (İ. Bakan (ed.)). Beta Basım Yayım Dağıtım A.Ş.

Paşaoğlu, D., Tokgöz, N., Şakar, N., Ergun Özler, D., \& İnan, Ö. (2013). Yönetim ve Organizasyon. Eskişehir: Anadolu Üniversitesi.

Pearce, J. A. I., \& Robinson, R. B. J. (1996). Strategic Management: Formulation, Implementation and Control. Long Range Planning, 29(6), 908.

Price, A. D. F., Ganiev, B. V., \& Newson, E. (2003). Changing Strategic Management Practice Within the UK Construction Industry. Strategic Change, 12(7), 347-366.

Söyler, İ. (2007). Kamu Sektöründe Stratejik Yönetim Uygulanabilir mi? Maliye Dergisi, 152, $103-115$.

Tokgöz, N., Ulukan, İ. C., Erdoğan, B. Z., Demirci, A. E., Baraz, A. B., Tiltay, M. A., Taşçı, D., \& Besler, S. (2014). Stratejik Yönetim-1. Eskişehir: Anadolu Üniversitesi.

Ülgen, H., \& Mirze, K. (2013). İşletmelerde Stratejik Yönetim. İstanbul: Beta Basım Dağıtım A.Ş. 